Vol. 23, No. 04, pp. 25-30, Year 2018

\title{
STUDY OF VIRULENCE FACTORS GENES AND ANTIBIOTICS SUSCEPTIBILITY OF STAPHYLOCOCCUS AUREUS ISOLATED FROM WOMAN WITH BREAST ABSCESS
}

\author{
Maitham Ghaly yousif a \\ Mohammed Hassan almayahi b \\ Qadisiyh University,Iraq-Collage of science, $\mathrm{Al}$ " \\ Qadisiyh University-Collage of science Biology department Al "
}

Email: husssaindaik@gmail.com

DOI: $10.29350 /$ jops.2018.23.4.907

\begin{abstract}
:
The aim of this study is isolating and diagnosing Staphylococcus aureus from breast abscesses in women using some morphological , serological and molecular methods as well testing the sensitive of isolates to antibiotic and molecular detection of virulence and resistant gene. Samples were collected from women with breast abscesses. The results of the biochemical tests,Api Staph and MASSTAPHAP explained 23 isolates of S.aureus bacteria Molecular diagnosis using 16srRNA gene confirmed morphological and serological diagnosis for all (23) isolates (100\%) with $27 \%$ of the total of eighty -Five clinical samples.

The results of the present study showed that the most age group exposed to S.aureus infection was (21 -30) years with $39.3 \%$. The most affected women were lactating woman $(29.31 \%)$. The percentage, especially for non-lactating women with breast mastitis and breast cancer, was $33.3 \%$. Antibiotic sensitivity test using disk diffusion method showed that the sensitivity of the $S$. aureus isolates to antibiotic was higher than the resistance .

Molecular detection using PCR technique showed that 21 isolates of the Luks gene (91.3\%) and 20 isolates had a blaz gene $(86.9 \%)$.
\end{abstract}

KEYWORDS: Staphylococcus aureus, virulence Factor, antibiotic

\section{Introduction}

Abscess are still the main bacterial infection among the patients, often caused by a bacterial infection. The abscess is shaped as an infected tissue containing pus. The breast appears to be "functional" and is not complex but in fact it is a group of critical pathological changes. These pathological changes, which are formed under the skin and come from a bacterial infection to be a painful mass within the breast is more likely to develop in women and can be repeated by $40-50 \%$ (Bharat et al.,2009), and more frequent "in women aged 15 to 60 years, especially in lactating women where the infection is either due to stagnation of the remaining milk and the breastfeeding of a new baby. Breast abscesses occur in women who are non-lactating woman Smokers and who have a weak immune system but is not common. This type of abscess should be differ from breast cancer because the symptoms of breast cancer characterized by exit of fluid from the breast (Salemis,2012) The patients with abscess may be accompanied by several signs including fever, increased white blood cells and irregular heartbeat. The breast may be swollen, painful, reddish and has critical complications such as septicaemia and toxic shock syndrome. It may affect the baby's health and early separation of the baby about breastfeeding (Kvist et al.,2007).

Most of the studies have shown the S. aureus is a common cause of breast abscess in women, (Kataria et al.,(2013) suggest that $S$. aureus is a common cause of abscess in lactating and non-lactating women.
Due to the importance of S.aureus bacteria as causes of diseases and lack of molecular studies related to the virulence factors of these bacteria, the present study aimed at detecting and determining the virulence factors in S.aureus bacteria isolated from female breast abscess using PCR technique through the following axes:

1- Isolation and identification of S.aureus and study the relation of this bacteria with breast abscesses in women.

2- Investigation of some genes responsible for the virulence factor using a PCR.

3- Detection the antibiotics sensitivity of the S.aureus isolates.

\section{Materials and Methods}

2.1 Samples collection

Eighty-five samples of breast abscesses were collected from Diwaniyah city hospitals, specifically in breast cancer consultation and early detection of breast cancer during the period from September 2017 to April 2018. The samples were collected under the supervision of the doctor and the surgeon, They were transported in sterile conditions by cotton conveyors to the laboratory.

\subsection{Isolation and identification}

The samples of the breast abscess were taken with sterile cotton swabs to the laboratory for no more than half an hour. The sample was streaked on the blood agar and brain heart infusion agar and the manitol salt agar. These media were incubated under air conditions at $37^{\circ} \mathrm{C}$ for 24 hours S.aureus bacteria were diagnosed on the basis of certain, microscopic and biochemical traits depending on both MacFaddine (2000) and Collee et al., (1996). 


\section{(QJPS)}

Vol. 23, No.04, pp. 25 -30, Year 2018

\begin{abstract}
2.3 Diagnostic System Test The System Analytical Profile Index (API)

This test was used to give a precise diagnosis of S.aureus bacteria. This test was carried out in accordance with the instructions of the French company Biomerieux, where sterile water droplets were placed on the groove on which the tape was placed to create wet conditions and then the suspension was prepared by transferring isolated and pure colonies In the center of the 24-hour nut medium to the center of the Staph medium liquid. Then the 20-hole tape was vaccinated with a sterile pipette. Then, close the tape in the dedicated folder and incubate at $37^{\circ} \mathrm{C}$ for 24 hours. Then compare the results with the API Staph(Alwakeel,2007).
\end{abstract}

\subsection{Serological identification}

This test was used for the ability of S.aureus bacteria to produce Protein A. The MASSTSTAPH solution was used according to the instructions of the US company MAST Diagnostic Virginia.USA by placing a drop of solution on a black piece or a clean glass slide and mixed with a colony of developing bacteria during 24 (30 - 60 seconds), it is observed that coagulation is more like intermittent milk and this is evidence that the result is positive.

\section{5 polymerase reaction test ( $\mathrm{PCR}$ )}

The test was performed to investigate some of the causes of virulence and antibiotic susceptibility in S.aureus (as follows):

1- Extracting the bacterial genomic DNA by the Kits according to the instructions of the processed company (Wizbio, Korea).

2- DNA testing by a Nano drop device to measure the concentration of DNA. This is detected by determining the concentration of DNA (ng / $\mu \mathrm{l})$ and measuring its purity by reading absorbance at a wavelength of 260-280 nm.

3- Prepare the PCR Master Mix using the Wizpure PCR kit and FDmix as instructed by the company fitted to it.

4- Preparation of agarose gel according to Sambrook et al.,(2001).

5.Electrical transfer of gel electrophoresis gel (1.5\%) under 100 volts and $80 \mathrm{~mA}$ at $60 \mathrm{~min}$ to detect extracted DNA and amplified DNA, which is amplified or PCR Product, according to Sambrouk et al.,(2001)

\subsection{DNA primers}

The genes used in the current study responsible for the virulence factors that were prepared by (Macrogene).

Table (1) The primers used in this study with their nucleotide sequence and amplification output size.

\begin{tabular}{|c|c|c|l|}
\hline $\begin{array}{l}\text { Size of } \\
\text { amplific } \\
\text { ation }\end{array}$ & \multicolumn{2}{|c|}{ Sequence of nitrogen bases } & Primers \\
\hline $556 \mathrm{bp}$ & F & TCAACCGTGGAGGGTCATTG & 16sRNA \\
\cline { 2 - 4 } & R & GTTTGTCACCGGCAGTCAAC & \\
\hline $447 \mathrm{bp}$ & F & ACAGTTCACATGCCAAAGAG & blaz \\
& R & TACCGAAAGCAGCAGGTGTT & \\
\hline $590 \mathrm{bp}$ & F & GATGGCGCTGAGGTAGTCAA & Luks \\
\hline & R & CCACTGTGTACTAATGGGGGT & \\
\hline
\end{tabular}

\subsection{Statistical analyse}

All the results of the present study were statistically analyzed, and the Statistical Package for Social Science (SPSS) was used for this purpose. Version 23, where the statistical test, square xi (chi-square) was applied for the purpose of comparing the percentages of all study variables. $95 \%$ and the probability level is less than 0.05 ( $\mathrm{P}<0.05)$ (Al-Ukaelii and Al- Shaeb.,1998).

\section{Results}

\subsection{Isolation and diagnosis of S.aureus bacteria}

The present study aimed to isolating and diagnosing S.aureus bacteria from women's breast abscess. In this study, 23 bacterial isolates of the S.aureus were found in 85 samples collected from women's abscesses and were diagnosed by studying microscopic characteristics and biochemical tests and using several MASSTSTAPH and API.

Biochemical tests were performed by growing isolates on the selective medium. The results showed a response of 23 isolates for the Catalase , Couagulase, the consumption of manitol, dnase test and blood analysis(100\%). 17 isolates were positive for Clamping factor, $(73.9 \%)$ With $(56.5 \%)$ producing Slime layer while all results were negative for the oxidase test.

\subsection{Diagnosis by MASSTSTAPH and APi Staph}

All isolates of the S.aureus bacteria were identified in this study by several MASSTSTAPH and APi Staph. All isolates showed positive results and $100 \%$ in the susceptibility of these isolates to protein A formation. All isolates were given $100 \%$ positive results of APi Staph and characterized by special colors S.aureus bacteria.

3.3 Numbers and percentages of S.aureus bacteria isolated from the female breast abscess

Twenty-three bacterial isolates of S.aureus were identified from the total number of samples of 85 cases of women abscess in women with a isolation $\operatorname{rate}(27 \%)$. The highest isolates of S.aureus were from nursing women and $29.31 \%$ followed by isolation rate of non-nursing women( $22.22 \%$ ).

Table (2): Numbers and percentages of isolating S.aureus bacteria according to the state of lactation

\begin{tabular}{|c|c|c|c|c|}
\hline $\begin{array}{c}\text { Feeding } \\
\text { status }\end{array}$ & $\begin{array}{c}\text { Number } \\
\text { of } \\
\text { samples }\end{array}$ & Percentage & $\begin{array}{c}\text { Number } \\
\text { of } \\
\text { positive } \\
\text { isolates }\end{array}$ & Percentage \\
\hline $\begin{array}{c}\text { lactating } \\
\text { women }\end{array}$ & 58 & $68.23 \%$ & 17 & 29.31 \\
\hline $\begin{array}{c}\text { non } \\
\text { lactating } \\
\text { women }\end{array}$ & 27 & $31.76 \%$ & 6 & 22.22 \\
\hline Total & 85 & $100 \%$ & 23 & 27.05 \\
\hline $\mathrm{X}^{2}$ & & & & $0.469^{*}$ \\
\hline $\mathrm{P}_{\text {value }}$ & & & & 0.493 \\
\hline
\end{tabular}

$\mathrm{X} 2$ represents the value of the calculated Kai box. *There were no significant differences at the 0.05 . 


\section{(QJPS)}

Vol. 23, No.04, pp. 25-30, Year 2018

The results were showed that the highest percentage of S.aureus isolates were infected women aged 30-21 and $39.3 \%$ as indicated in Table 5, while the lowest percentage of S.aureus isolates was from infected women of age (6051), 61 and more by isolation ratios, $12.5 \%$ and $0 \%$, respectively.

Table (3) Distribution of S.aureus infection by age group and percentage of women

\begin{tabular}{|c|c|c|c|}
\hline age & $\begin{array}{l}\text { Number of } \\
\text { samples }\end{array}$ & $\begin{array}{l}\text { Number of } \\
\text { isolates }\end{array}$ & percentage \\
\hline $20-11$ & 9 & 2 & $22.22 \%$ \\
\hline $30-21$ & 33 & 13 & $39.39 \%$ \\
\hline $40-31$ & 21 & 5 & $23.81 \%$ \\
\hline $50-41$ & 11 & 2 & $18.18 \%$ \\
\hline $60-51$ & 8 & 1 & $12.5 \%$ \\
\hline 61 and & 3 & 0 & $0 \%$ \\
\hline More & & & 27.05 \\
\hline Total & 85 & 23 & $5.174 *$ \\
\hline$X^{2}$ & & & 0.395 \\
\hline$P$ value & & & \\
\hline
\end{tabular}

$\mathrm{X} 2$ represents the value of the calculated Kai box.

*There were no significant differences at the probability level of 0.05 .

In this study, all 85 cases were observed. Some clinical cases of women with breast abscess were $100 \%$, with $96.4 \%$ fever. A combined abscess called Mass was observed with $94.1 \%$ and a $100 \%$ abscess showed as shown in Table

Table (4) Some clinical symptoms of 85 cases of women with breast abscess .

\begin{tabular}{|c|c|c|c|}
\hline $\begin{array}{c}\text { Clinical } \\
\text { symptoms }\end{array}$ & $\begin{array}{c}\text { Number of } \\
\text { Samples }\end{array}$ & $\begin{array}{c}\text { Number } \\
\text { of injured }\end{array}$ & percentage \\
\hline Pain & & 85 & $\% 100$ \\
\hline Fever & & 82 & $\% 96.47$ \\
\hline Mass & \multirow{2}{*}{85} & 80 & $94.11 \%$ \\
\hline \multirow{2nn}{*}{$\begin{array}{c}\text { Abscess } \\
\text { of abscess }\end{array}$} & & 85 & $100 \%$ \\
\hline$X^{2}$ & & & $9.212 *$ \\
\hline P value & & & 0.027 \\
\hline
\end{tabular}

X2 represents the value of the calculated Kai box *There were significant differences at a probability level of 0.05
As noted in the present study, the number of non-lactating women with 27 abscesses and isolates of S.aureus $26 \%$ was 6 isolates with the highest percentage of S.aureus isolates in nonbreast cancer patients with breast cancer and inflammation In the breast Mastitis isolation rate $33.3 \%$, and the lowest percentage of women who have no sign of the disease, where the percentage of $0 \%$ by 3 cases as shown in Figure (1)

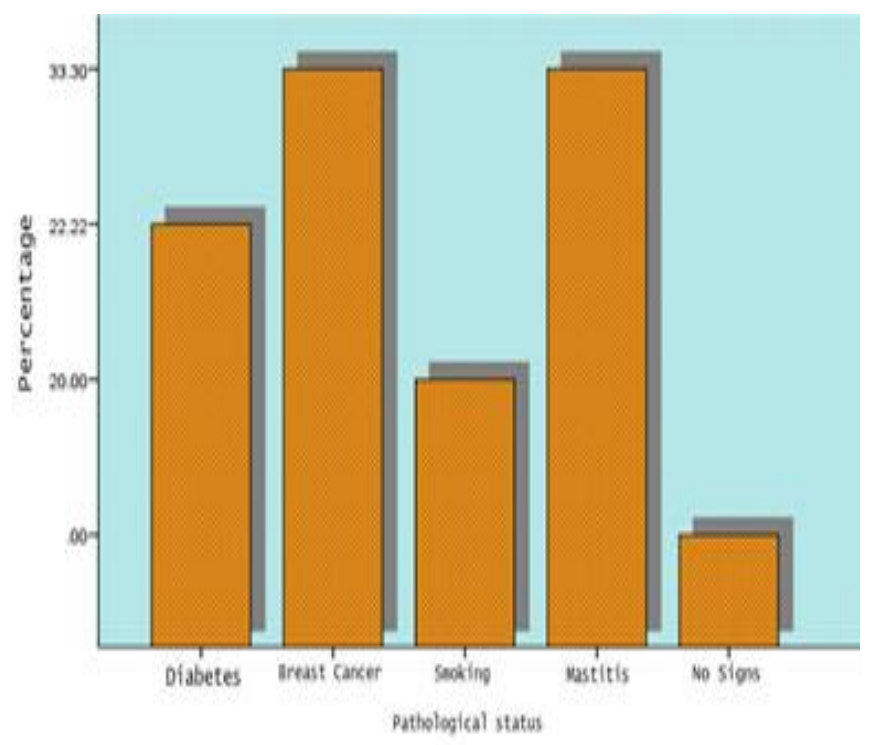

Figure (1) S.aureus infection (total number 6) for non-Lactating women by disease status.

\subsection{Antibiotic Susceptibility Test}

All isolates of S.aureus were tested for 18 antibodies. The results showed that there were significant differences in the resistance of the bacteria under study for antibiotics, as shown in $\operatorname{Fig}(2)$.

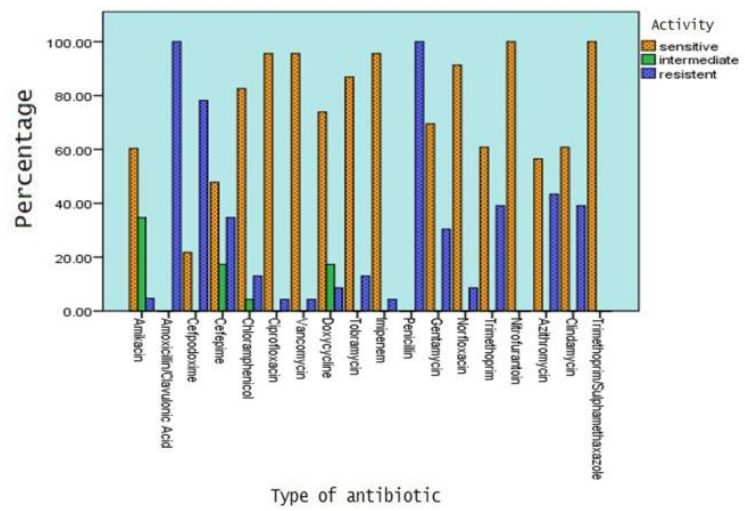

Figure (2) sensevity and resistant of S.aureus for the antibiotic. 


\section{(QJPS)}

Vol. 23, No.04, pp. 25 -30, Year 2018

Some virulence genes were identified for S.aureus isolates from the 23 female breast abscess using PCR technique The gene responsible for Leukocidine, the gene responsible for the blazes and the gene responsible for skin flaking was investigated. 21 isolates possessed a Luks gene (91.3\%) and 20 isolates $(86.9 \%)$ possessed For the blaz gene, as well as the diagnostic gene for 16 srRNA gene and by $(100 \%)$.

\section{Discussion \\ 4.1 Isolation and diagnosis of S.aureus bacteria}

In this study, samples were collected from women's breast abscess for the purpose of knowing the incidence of S.aureus bacteria in women's breasts and as a result of breast infection in nursing and non-nursing women and the consequent eradication of women's lumbar gland and consequent psychological and physical harm, Surgical and therapeutic interventions to treat the condition and not exacerbate

The implantation was performed by means of cotton bands on the center of the solid blood acre with 24 hours of air conditions. The colonies appeared bright, smooth, medium size with a diameter of $3-1 \mathrm{~mm}$ and a translucent halo around beta-haemolytic colonies.

The medium Staphylococcus Medium NO 110 was( orange color) and Manitol Salts Agar (Yellow Gold) was found to be consistent with Colle et al. (2000).

\subsection{Diagnosis of Api Staph and MASSTAPH}

Several Staph APIs were used to confirm the diagnosis of isolates and were diagnosed with primitive biochemical tests. The S.aureus isolates demonstrated that they could ferment many sugars, including glucose, sucrose, fructose, and nitrate, and gave them a positive result for VP testing and production of urease and phosphatase. (Alwakeel,2007) S.aureus bacteria were investigated for protein A production by MASSTSTAPH. All isolates were positive in terms of coagulation but at varying time intervals. This protein is a surface protein of S.aureus which stimulates adhesion to the host surface and is necessary for this bacteria (Grinholc et al.,2007).

Table 2 showed the higher incidence of breast abscess in lactating women compared to non-nursing women. These results are low compared to the results of Kadum, (2006), which indicated that breast abscess is common in nursing women. The percentage of S.aureus isolates was $74.6 \%$ and very rare among women Non-lactating with a $25.4 \%$ isolation rate.

According to Efem, (1995), breast abscess is $95 \%$ for lactating women and $5 \%$ for non-lactating women. The incidence of breast abscess in non-nursing women is lower because smoking leads to an increase in milk ducts and reduced immunity, such as diabetes and inflammation Rheumatoid joints and shock to the abscess of breast in nonbreast-feeding women. The high incidence of S.aureus infection in lactation can be attributed to several causes, including breast-borne infections through transmission of bacteria to the breast tissue by scratches or cracks on the nipple during Breastfeeding leads to blockage In the milk duct and this leads to the stagnation of milk and emptying it, which causes inflammation of the breast and the occurrence of abscess if not treated quickly and poor personal hygiene (Surani et al.,1993).

Table 3explained the distribution of S.aureus infection according to the age groups of infected women. In this study, the number of cases of breast abscess was increased in the age group (21-30). The number of cases was 33 cases in the abscess of the breast. The number of isolates was $13.3 \%$, followed by the age group (31-40), with 21 isolates with a positive isolation rate of $23.8 \%$. This was attributed to the high incidence of reproduction and lactation in this age and the stagnation of milk, which is an important factor In the formation of abscess, in the age group (41-50), the infection rates were observed at (18.1\%) Who concluded that breast abscess in non-nursing women was three to eight decades of life and also agreed with Surani et al., (1993) that breast abscess was uncommon and rarely occurs in non-lactating women and could occur after age 40 Of life, while the incidence of S.aureus infection decreased in the age groups (60-51) and (61-70) where it was (12.5\%) and (0\%), respectively.

The results of Table (4) showed the clinical symptoms of 85 women with breast abscess. These results were agreed with Marchant,(2002).

This is due to the fact that the injury may occur in the breast tissue causing swelling of the tissue outside the milk duct.

This swelling may press the lactic canal, Pain, swelling and redness Russell et al. (2004) reported that the infected breast was accompanied by several signs, including fever, mass and severe pain.

Breast abscess is common in lactating women but recently breast abscesses from non-lactating women have been observed to rise The results of our study, as shown in Figure 1, showed that S.aureus infection of non-nursing women in the number of cases examined was 27 with a $26 \%$ isolation rate, The highest rate of isolation of bacteria in non-breast-feeding women with breast cancer and breast infection is $33.3 \%$. This may be due to reduced patient immunity and patient age, as well as the reviews performed by hospitalized women leading to S.aureus In addition, as indicated by the current study of non-lactating women who suffer from diabetes, the percentage of isolation of S.aureus bacteria $22.2 \%$ This may lead to a decrease in the immunity of the patient, exposing her to S.aureus infection was consistent with what Verghese and Raviknath,(2012), who concluded that It is possible that the abscess of the breast may be associated with diabetes.

Smoking may be a major cause of the development of the primary cysts and recurrence, where the percentage of isolation of bacteria from women smokers not nursing $20 \%$ not only smokers, but even exposed to smoking as it is possible that the toxins are secreted into the vessels of the channel, which leads to the destruction of the milk duct (Bharat et al.,2009). In Saudi Arabia, (Abdelhadi and Bukhari 2005) found 26 cases of nonlactating women with breast abscess, with 50\% suffering from breast cancer (Al-abdely et al., 1996) Of mastitis, $11.5 \%$ of diabetes and $7.6 \%$ of meningitis Pat breast cancer.

\subsection{Antibiotic Suscibility Test}

The pharmacological sensitivity of all isolated S.aureus isolates from the female breast abscess using 18 types of antibiotic in the form of pill spread was chosen. These antibiotics were selected according to CLSi, (2016) and compared to their 


\section{(QJPS)}

Vol. 23, No.04, pp. 25 -30, Year 2018

respective tables. These antibodies were used to determine the antibiotic resistance and sensitivity of the bacteria And to give appropriate treatment to eliminate S.aureus bacteria that cause breast abscess in women.

4.4 Investigation of the virulence factors resistant gene of S.aureus bacteria using PCR technique

All isolates of S.aureus bacteria were tested in the current study for diagnosis of S.aureus bacteria using 16srRNA. All isolates contained this gene. These results were similar to Saruta et al.,(1995), which tested 28 isolates of Staphylococcus aureus using PCR technology. The results of the present study showed that there are 20 isolates with( $86.9 \%$ ) having a blaz gene where resistance to penicillin is shown by producing the enzymes of the home, which is encoded by a blaz gene containing three types A, B, C) According to CLSI's The purpose of isolating S.aureus bacteria from cases requiring treatment with penicillin (Pereira et al.,2014). The high rate of presence of the toxin gene $(91,3 \%)$ in the present study may be due to the source of isolation of these bacteria, which is the abscess of the breast, due to the close association between The incidence of this gene was( $91.3 \%)$.

The presence of this gene in the present study was higher than that of the Viques and others (Víquez et al.,2018).

\section{References}

-Al Abdely, H. M., Halim, M. A., \& Amin, T. M. (1996). Breast abscess caused by Brucella melitensis. Journal of Infection, 33(3), 219-220.

-AbdelHadi, M. S., \& Bukharie, H. A. (2005). Breast infections in non-lactating women. Journal of family \& community medicine, 12(3), 133.

-Al-Ukaelii, S. A. and Al- Shaeb, S. M. (1998). Statically Analysis by used SPSS Program .Al-Shoroq house for Publishers and advertisement Amaan, Jordan.

-Alwakeel, S. S. (2007). Bacterial and Aspergillus spp. contamination of domestic kitchens in Riyadh, Saudi Arabia. Saudi J. Biol. Sci, 14(1): 1-6.

•Bharat, A., Gao, F., Aft, R. L., Gillanders, W. E., Eberlein, T. J., and Margenthaler, J.A. (2009). Predictors of primary breast abscesses and recurrence. World journal of surgery. 33(12): 2582-2586.

- Clinical and Laboratory Standards Institute (CLSI) . (2018) - Performance standards for Antimicrobial Disks Susceptibility tests.Vol.31 No.1 Jan.
•Collee, J. G.; Fraser, A. G.; Marmiom, B. P.; and Simmon, A. (1996). Mackie and McCarteny, Practical Medical Microbiology. $4^{\text {th }}$ ed. Churchill Livingstone inc., USA.

•Efem, S. E. (1995). Breast abscesses in Nigeria: lactational versus non-lactational. Journal of the Royal College of Surgeons of Edinburgh, 40(1), 25-27.

•Grinholc, M., Wegrzyn, G., \& Kurlenda, J. (2007). Evaluation of biofilm production and prevalence of the icaD gene in methicillin-resistant and methicillin-susceptible Staphylococcus aureus strains isolated from patients with nosocomial infections and carriers. FEMS Immunology \& Medical Microbiology, 50(3), 375-379.

-Kadum, H. N. (2006). A Clinical and Bacteriological Study of Breast Abscess In Female Patients, 11(2), 359-364.

-Kataria, K., Srivastava, A., \& Dhar, A. (2013). Management of lactational mastitis and breast abscesses: review of current knowledge and practice. Indian Journal of Surgery, 75(6), 430435.

•Kvist, L. J., Hall-Lord, M. L., \& Larsson, B. W. (2007). A descriptive study of Swedish women with symptoms of breast inflammation during lactation and their perceptions of the quality of care given at a breastfeeding clinic. International breastfeeding journal, 2(1), 2 .

-MacFaddin, J. F. (2000). Biochemical Tests for Identification of Medical Bacteria 3rd ed. Lippincott Williams and Wilkins, USA.

-Marchant, D.J. (2002). Inflammation of the breast. Obstet. Gynecol. Clin. Nor. Am., 29(1): $89-102$.

•Pereira, L. A., Harnett, G. B., Hodge, M. M., Cattell, J. A., \& Speers, D. J. (2014). Real-time PCR assay for detection of blaZ genes in Staphylococcus aureus clinical isolates.Journal of clinical microbiology, 52(4), 1259-1261.

-Russell, R.G., William, N.S. and Bulstrode, C. J.K. (2004). Short practice of surgery, 24th Ed., Hodder headline group, London.

-Salemis, N. S. (2012). Breast abscess as the initial manifestation of primary pure squamous cell carcinoma: A rare presentation and literature review. Breast disease, 33(3), 125131.

-Sambrook, J.; Maccallum, P. and Russel, D. (2001). Molecular Cloning: a Laboratory Manual, 3nd ed, Cold Springs Harbour Press, New York, p: 2344. 


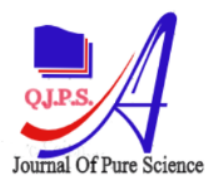

Al-Qadisiyah Journal of Pure Science

\section{(QJPS)}

Vol. 23, No.04, pp. 25 -30, Year 2018

-Saruta, K., Hoshina, S., \& Machida, K. (1995). Genetic identification of Staphylococcus aureus by polymerase chain reaction using single-base-pair mismatch in $16 \mathrm{~S}$ ribosomal RNA gene. Microbiology and immunology, 39(11), 839-844.

-Surani, S., Chandana, H. and Weinstein, R.A. (1993). Breast abscess: Coagulase negative Staphylococcus as a sole pathogen. Clin. Infect. Dis., 17(4): $701-4$.

-Verghese, B. G., \& Ravikanth, R. (2012). Breast abscess, an early indicator for diabetes mellitus in non-lactating women: a retrospective study from rural India. World journal of surgery, 36(5), 1195-1198.

-Víquez-Molina, G., Aragón-Sánchez, J., Pérez-Corrales, C., Murillo-Vargas, C., López-Valverde, M. E., \& Lipsky, B. A. (2018). Virulence Factor Genes in Staphylococcus aureus Isolated From Diabetic Foot Soft Tissue and Bone Infections .The international journal of lower extremity wounds, 17(1), 36-41. 